\title{
On a Remarkable Process of Bud Formation in a Gymnoblastic Hydroid (Heterostephanus sp.).
}

\author{
By \\ W. J. Rees, \\ Research Assistant at the Plymouth Laboratory.
}

With 3 Figures in the Text.

THE process of asexual reproduction described below, is, as far as the writer is aware, unique among hydroids. In all known species of hydroids in which an asexual bud formation has been described (e.g. in Hydra), the mouth and oral tentacles develop at the free end of the bud and the proximal or fixed end becomes the base. The sequence of development of medusa buds is essentially similar. This method applies also to budding in other Coelenterates. In the present instance the bud instead of growing out "head first," came off "tail first "- the proximal end developing mouth and oral tentacles and the free end becoming the stalk. I can find no record of such a method having been described before.

The hydroid on which it occurred was dredged from below low-water mark near the eastern end of the Plymouth Breakwater. The polyp was found on a piece of hapteron (the so-called " root") of Laminaria cloustoni on July 9th, 1936, that had been allowed to stand in sea-water for two days. When first observed the polyp was in a very contracted condition, so it was picked off the hapteron and removed to another bowl for a further period of two days.

On July 14th the hydroid was seen well expanded (Fig. 1). It consisted of a solitary polyp bearing some resemblarce to a young polyp of Corymorpha nutans M. Sars, 1835, having oral and aboral tentacles. It differed from this hydroid in that the four oral tentacles were capitate and the eight aboral tentacles were moniliform; the latter in two closely approximated whorls of four long and four short ones. The longer tentacles carried 10-12 batteries and the shorter 6-7 batteries of nematocysts completely encircling the tentacle. Both tentacles and the stalk were very contractile, capable of expanding to five times their contracted length. The posterior end of the hydranth carried four backwardly directed papillae. The stalk was covered by a membranous hyaline perisarc. The total height of the polyp was $3 \mathrm{~mm}$.

On July 17th a swelling appeared on the body of the polyp at the level 
of the longer whorl of tentacles carrying outwards with it one of the long tentacles. On the next day this swelling was clearly seen to be some kind of " bud." Small processes, four in number, appeared on the level of the long tentacle (Fig. 2). At this stage the number of nematocyst rings on

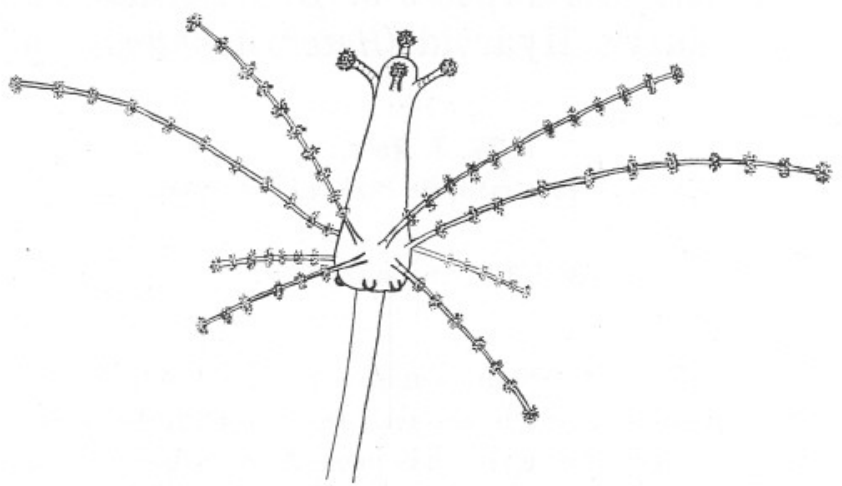

FIg. 1.-Heterostephanus sp., from the hapteron of Laminaria cloustoni, hydroid fully expanded with part only of the hydrocaulus shown; Plymouth, 9.vii.36.

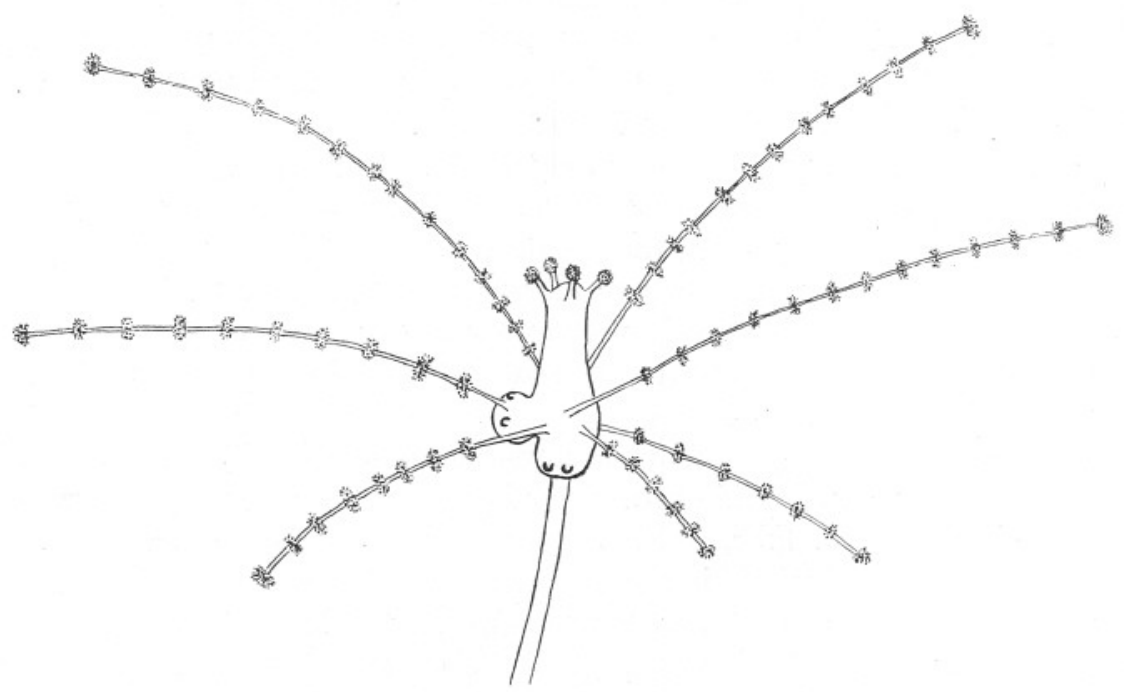

Fig. 2.-Heterostephanus sp., first stage of the formation of the bud (lower part of the hydrocaulus not shown); Plymouth, 18.vii.36.

some of the tentacles of the parent polyp had increased. One long tentacle now possessed fifteen rings and a shorter tentacle had eight.

Two days later the bud had grown in size and its free end had become transparent and pointed. The four processes already noted had grown 


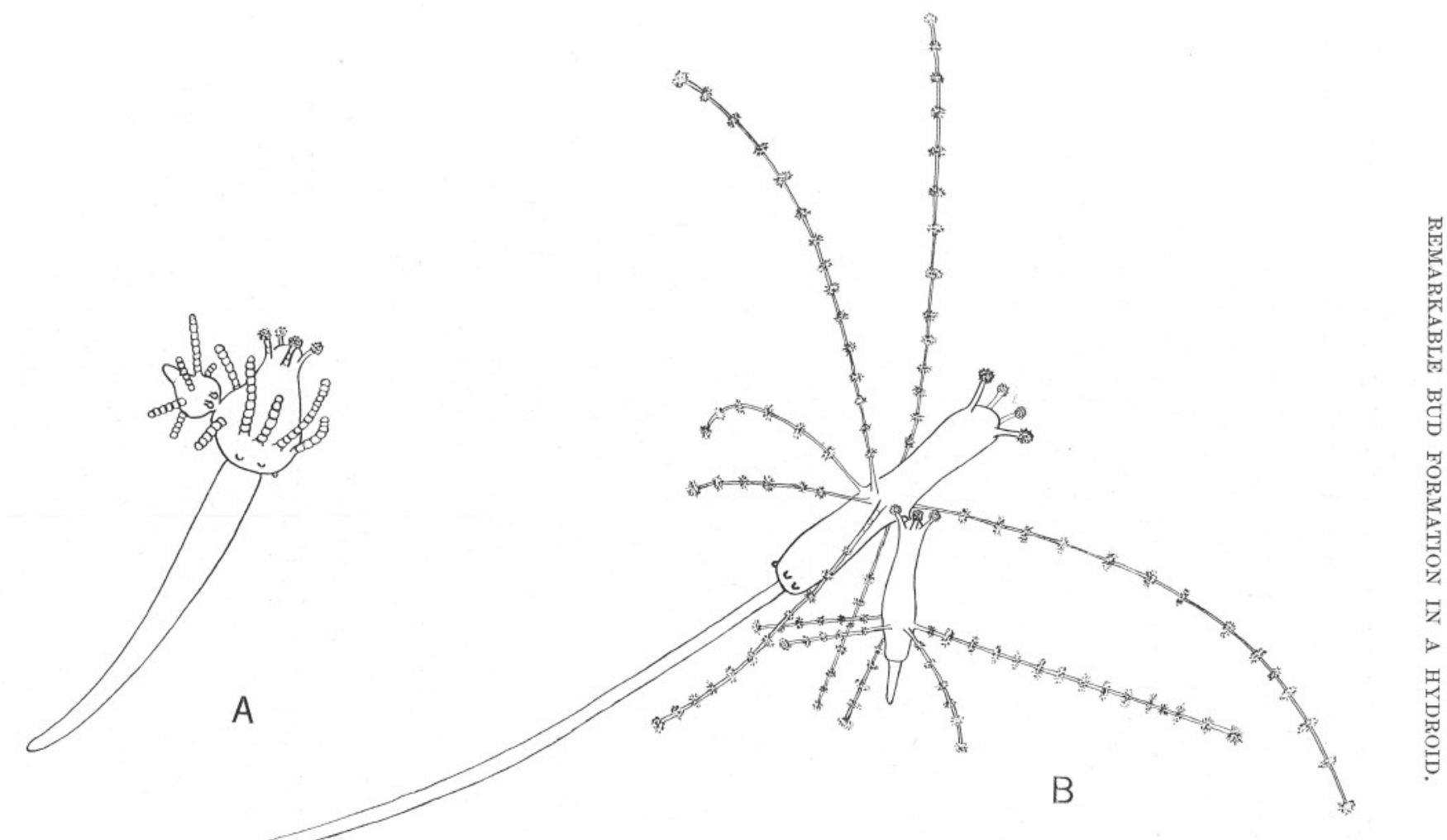


out into short annulated tentacles each with 4-6 rings. Small processes were also observed developing near the point of attachment of the bud (Fig. 3, A).

Next day (July 21st) the bud had elongated considerably. The small processes noted the previous day had developed into four capitate tentacles (Fig. 3, в). The free end had become quite distinct and resembled the stalk of the parent. On the same day the bud broke away and quickly settled down on the bottom of the bowl, attaching itself within thirty minutes of becoming free. Before nightfall, the stalk had elongated considerably (to about half the length of the stalk of the parent). Both polyps died on July 23rd, probably due to overfeeding.

On September 29th a second polyp was found among some fine gravel from the Eddystone by Dr. M. V. Lebour, who kindly gave me the polyp for examination. When found it was in a much contracted condition, but by next day it was fully expanded and could be definitely recognized as belonging to the same species as the one which I had previously found. The hydranth was brownish in colour and possessed four oral capitate tentacles and four long and two shorter aboral tentacles. The membranous perisarc was distinct and of a slightly brownish colour and better developed than in the first polyp found. At the posterior end of the hydranth there were four papillae directed backwards. The length of the hydranth expanded was $1 \mathrm{~mm}$., the length of the hydrocaulus when expanded was $1.4 \mathrm{~mm}$. and $0.45 \mathrm{~mm}$. when contracted. The polyp lived only three days after it was found.

While the bud-formation described above may probably be the usual way of asexual reproduction in this species, the carrying away of one of the parent polyp's tentacles is perhaps not typical but depends on the point of origin of the bud.

\section{Systematic Position.}

This hydroid appears to be closely related to the genera Rhizotrichia Stechow, 1919 (=Trichorhiza Russell, 1906), Heterostephanus Allman, 1864, Acharadia Wright, 1863, and Vorticlava Alder, 1857. It is distinguished from Acharadia and Vorticlava by its aboral tentacles being annulated with clusters of nematocysts; from Rhizotrichia by its simple undivided hydrocaulus and by the possession of only four oral capitate tentacles. It appears, however, to be more nearly related to Heterostephanus annulicornis (M. Sars, 1860). It seems to differ from this last species in having only four oral tentacles, fewer aboral tentacles, in its thin perisarc, much smaller size and delicate appearance. All these differences may be due to age and growth and my specimens may possibly be young hydroids of $H$. annulicornis. Until knowledge of the gonosome 
of my species is obtained I do not feel justified in assigning it to $H$. annulicornis or to any other species and simply place it provisionally in the genus Heterostephanus Allman.

\section{REFERENCES.}

Alder, Joseph. 1857. A Catalogue of the Zoophytes of Northumberland and Durham. Tyneside Nat. Field Club, Vol. 3, pp. 93-162, Pl. 3-10.

Allman, G. J. 1871-72. A Monograph of the Gymnoblastic or Tubularian Hydroids. Ray Soc., London, pp. 1-450.

Russell, E. S. 1906. On Trichorhiza, a new Hydroid genus. Proc. Zool. Soc., London, pp. 99-101.

SARs, M. 1860. Udtog af en Afhandling, som med de tilhørende talrige Afbildninger er bestemt for naeste Hefte af Fauna littoralis Norvegiae om Ammeslaegten Corymorpha og dens Arter samt de af disse opammede meduser. Forhandl. i Vid. Selsk. i Christiania, 1859, pp. 96-105.

1877. New and little known Coelenterates. Fauna Littoralis Norvegiae, iii; pp. 1-48, Taf. i-ii.

Stechow, E. 1923. Zur Kenntnis der Hydroidenfauna des Mittelmeeres, Amerikas und anderer Gebiete. Zool. Jahrb. Syst., Bd. 47, pp. 29270 .

Wright, T. Strethill. 1863. Observations on British Zoophytes. Quart. Journ. Micro. Sci. (N.S.), Vol. 3, pp. 47-52, Pl. 4-6, London. 